\title{
PROBLEMS ENCOUNTERED WHILE REVISING THE PROVERB LORE IN A GENERAL BILINGUAL DICTIONARY
}

\author{
Peter BARTA \\ ELTE University, French Language and Literature Department \\ H-1145 Budapest, Amerikai út 96, Hungary
}

IN MEMORIAM FERENC BAKOS

\begin{abstract}
The revision of the proverb lore in the French-Hungarian and Hungarian-French Dictionary to be published in Hungary in the near future forced me to give quite quick and short answers to questions that should deserve due consideration, i.e.:

- How to determine the quantity and quality of proverbs that should be included in a (nonphraseological) bilingual dictionary?

- How to deal with proverbs no equivalent of which is known in the other language?

- To what extent are details needed/permitted about the different uses of individual proverbs?

- Under what and how many key words should a proverb appear?

- Should we suppress the distinction between the labels proverb and proverbial expression because of the relationship between them?

- When the entry is divided into several parts for semantic or grammatical reasons, should we place the proverbs separately at the end of each part or together at the end of the entry?

I have no universal answer to these questions, but I may contribute to the reflection by giving some ideas.

Keywords: dictionary, lexicography, paremiology, paremiography, phraseology, proverb, Hungarian proverbs, French proverbs
\end{abstract}

\section{INTRODUCTION}

A new French-Hungarian and Hungarian-French Dictionary is going to be published in Hungary in the near future. "New" means here a completely revised version of the one that has been in use for 40 years now.

I have been studying proverbs for many years but this was the first time that I was involved in the revision of the proverb lore in a general bilingual dictionary. As a consequence, I had to face problems that I was unfamiliar with and that led me to another field of linguistics: lexicography. Moreover, the problems I will now tackle are not the ones related to the compilation of the proverb material for a new dictionary but those concerning the revision of the proverb lore in an already existing one.

As a matter of fact, revision offers quite limited choices for the editor. Time, space, the previous edition, the division of labour, etc., these very practical considerations restrict one's scope. During the work, the problems must be solved on a pragmatic basis. Lengthy considerations may only come afterwards, e.g. at a conference between specialists or in an article.

It is well-known that proverbs have a somewhat special role in dictionaries. A proverb is a transposition, it is at some distance from reality, so it is a kind of trans- 
lation itself. That is why it is difficult to find its equivalent. To put it in another way: we have to look for the equivalents of lexical items on the $1^{\text {st }}$ level and of proverbs on the $2^{\text {nd }}$.

During the revision of the proverb lore, I encountered four major problems for which I had to find solutions.

The first one was the quantity of proverbs to be included in a non-phraseological dictionary. The second one was which proverbs to include, the third one the question of labelling and the fourth one was the place of the proverbs in the entry.

\section{THE QUANTITY OF PROVERBS}

After long consideration, I stuck to the obvious interest of the publisher of not making changes where it is not necessary, which resulted in the inclusion of about 500 proverbs of each of the two languages. But I am still uncertain about what would be the right quantity - or rather: the right proportion - of proverbs in a general bilingual dictionary.

\section{WHICH PROVERBS SHOULD BE INCLUDED?}

There exist frequency lists for the proverbs most often used of both languages: in Hungarian in Anna TótH-LitovkinA's Ph. D. thesis ${ }^{1}$ and in French in Pierre ARNAUD's article. ${ }^{2}$ Sometimes even the proverb dictionaries may indicate the frequency of occurrence, like Gyula PACZOLAY's one ${ }^{3}$.

I also included some obsolete proverbs although it is a dictionary of contemporary language. I tried to select the proverbs that are currently in use when I had several variants to choose from but when I had no choice, I thought it was better to have an obsolete proverb than to have no equivalent at all.

Talking about variants: I sometimes found that a proverb did not appear in the same form in the French-Hungarian part and in the Hungarian-French part. After some reflection, I came to the conclusion that it is not necessary to unify them just for the sake of uniformity. Even if it came to a user's wicked mind to compare the French-Hungarian part with the Hungarian-French part, he could have no objection against finding two different forms if both are correct.

The fact that this is a bilingual and not a monolingual dictionary forced me to compromises. I also included proverbs the equivalent of which is not a contempora-

1 Tóthné LitovkinA, Anna (1993): Felmérés a magyar közmondások ismeretére vonatkozóan és a felmérésben legismertebbnek bizonyult közmondások elemzése. Kandidátusi disszertáció [Survey about the Currency of Hungarian Proverbs and Analysis of the Best Known Proverbs according to the Survey. Ph. D. Thesis]. Budapest.

2 ARNAUD, Pierre (1992): La connaissance des proverbes français par les locuteurs natifs et leur sélection didactique [The Knowledge of French Proverbs by Native Speakers and their Didactic Selection]. In: Cahiers de Lexicologie LX (1992-I) 195-238.

3 PACZOLAY, Gyula (1987): A Comparative Dictionary of Hungarian-Estonian-German-EnglishFinnish and Latin Proverbs with an Appendix in Cheremis and Zyryan. Veszprém. 
ry proverb but an obsolete one, a proverbial phrase or just a translation. Had this not been done, many proverbs that are characteristic of language $\mathrm{A}$ or frequently used in language $\mathrm{A}$ would have been omitted for the very reason of having no equivalent in the form of a contemporary proverb in language B.

\section{LABELLING}

It is undoubtedly necessary to indicate whether a certain utterance in the dictionary is a proverb or not. It may be important information for the user, e.g. when there is a proverb in language $\mathrm{A}$ and in the absence of a proverbial equivalent, the dictionary gives a non-proverbial equivalent in language B. One can use capital letters to indicate that a certain utterance is a proverb. But when the proverb begins with the entry-word (which is quite a frequent case), the opposition minuscule vs. capital is neutralised by the use of the tilde, e.g. in

Example 1:

\section{Idleness is the root of all evil $\leftrightarrow \sim$ is the root of all evil.}

The proverb Idleness is the root of all evil will probably be found under the entry idleness, so it will appear in the following form: $\sim$ is the root of all evil. The capitals are not the right solution for another reason too: they are also used to identify proper names.

Another means is the abbreviation (prov) used before or after the proverb. But it occupies space. Moreover, this label often has to be used twice, to indicate that both the utterance in language $\mathrm{A}$ and its equivalent in language $\mathrm{B}$ are proverbs. Sometimes, the equivalent of a proverb in language $\mathrm{A}$ is non-proverbial in language $\mathrm{B}$, because, as we have seen, there does not exist such a proverb in language $\mathrm{B}$. Then the label (prov) has to be placed before or after the proverb in language A. But if the equivalent is a proverb too, the label (prov) has to be used a second time. The publisher would rather not lose so much place.

The question is not simply where to use the label but which label to use: proverb and proverbial phrase separately for the two kinds of utterances or proverbium for both, without making a difference? Let's see the arguments.

I found in many cases that the equivalent of a proverb in language A is a proverbial phrase in language B. Two examples will illustrate this phenomenon in the correspondence between French and Hungarian:

Example 2:

Au bout du fossé la culbute (proverb) ['at the end of the ditch, the somersault', i.e. the worst is yet to come]

hátravan még a feketeleves (proverbial phrase) ['the black soup is yet to come', i.e. the worst is yet to come] 
Example 3:

Qui ne veut bât, Dieu lui donne selle (proverb) ['to the one that doesn't want a pack, God will give a saddle', i.e. out of the frying pan into the fire]

cseberból vederbe (proverbial phrase) ['out of the bucket into the pail', i.e. out of the frying pan into the fire]

but one would probably be confronted with the same difficulty in the correspondence between English and other languages, as one can see it within one language too:

Example 4:

Don't put the cart before the horse (proverb)

to put the cart before the horse (proverbial phrase)

The proverbium label would make it possible to motivate the matching of the two equivalents one of which is a proverb and the other is a proverbial phrase. But at the same time, it would mislead the user; it would make him believe that the two utterances can be used in a similar grammatical context although in reality they cannot.

The conception according to which proverbs and proverbial phrases should have different labels makes it possible to have two editors for the two categories. But then, which editor's task is it to revise such equivalences as the ones in examples 2,3 and 4 ? If we accept that proverbs and proverbial phrases should have the same proverbium label, then the answer is: the same editor should do the revision. This very question is also asked and the same answer is given in the case of utterances which can be, without a morphological change, proverbs and proverbial phrases in a language, e.g.

\section{Example 5:} out']

Kibújik a szög a zsákból (proverb) ['man’s true nature will always

kibújik a szög a zsákból (proverbial phrase) ['sy's true but hidden intention appears']

Example 6:

Elöbb jön a dínomdánom, azután a szánombánom (proverb) ['excessive joy will usually be followed by sorrow']

elóbb jön a dínomdánom, azután a szánombánom (proverbial phrase) ['this pleasure will be followed by a long repentance']

Example 7:

Egyszer hopp, másszor kopp (proverb) ['it is natural that sometimes one is well off, at other times one is poorly off'] 
egyszer hopp, másszor kopp (proverbial phrase) ['sometimes he is well off, at other times he is poorly off']

Example 8:

Könnyú Katót táncba vinni (proverb) ['it is easy to persuade somebody who is willing']

könnyú Katót táncba vinni (proverbial phrase) ['he/she is willing but won't admit it']

Example 9:

Meghalt Mátyás király, oda az igazság (proverb) ['justice is not done']

meghalt Mátyás király, oda az igazság (proverbial phrase) ['not to know where to ask for justice']

All these technical considerations and the obvious theoretical ones suggest the use of the proverbium label. And yet, let us not forget a counter-argument of crucial importance: it is a general dictionary and not a phraseological one. The user might not be familiar with the recent findings of this very branch of science.

To conclude, I would not recommend the use of the proverbium label until it has become a familiar term to the ordinary user. But this time is not far ahead.

\section{THE PLACE OF THE PROVERBS}

The next problem is where to place the proverbs in the dictionary. Many possible solutions have been identified and used.

- There is a method favoured in some proverb dictionaries to have a straight alphabetical sequence on the basis of the first letter of the first word.

- Another option is the thematic presentation.

It is impossible for us to apply either the first or the second method because the general dictionaries are made up of entries and the proverbs, too, must appear at these entries. In fact, we are confronted here with the problem that what we are doing is at the intersection of paremiography and lexicography.

So the question has got narrower: at which entry should a proverb be placed? The answer is: under the first significant word. But which one is that? The problems encountered with the selection of the first significant word have been lengthily discussed in the special literature, so I do not wish to begin anew the discussion. It may be the first or the second noun, verb, adjective or adverb. To counterbalance this uncertainty, many proverb dictionaries use a thematic index. This being impossible in a general dictionary, I advise, where necessary, i.e. when the first significant word cannot be identified for sure, to list the proverb in two entries. The proverb and its equivalent may be written in full, or - to use less space - a cross-reference should be made indicating under which other entry the proverb can be looked up. 
Where within the entry should the proverb be? In fact, an entry may be divided into several parts on a semantical or morphosyntactical basis. Let's see a concrete case:

Example 10:

\section{All that glitters is not gold}

This proverb should appear at the entry gold, but under which unit of meaning: 1) metallic element in chemistry; 2) a gold coin; 3 ) a gold piece; 4) money? ${ }^{4}$ So there are two solutions for the multisense words:

a) the proverbs appear at the end of each unit of meaning (for gold, for example, after 1), 2), 3), or 4);

b) the proverbs appear at the end of the entry.

There are two arguments in favour of solution b). The first one is that proverbs often have a metaphorical quality, no wonder that it is often difficult to say which of the meanings is relevant. The second one is that if we adopt solution a), two proverbs at the same entry may appear under two different units of meaning. E.g. All that glitters is not gold may be listed under meaning 1) and

Example 11:

\section{Gold may be bought too dear}

under meaning 4).

In the case of the new French-Hungarian and Hungarian-French Dictionary, the strongest argument regarding the previous matter proved to be the force of inertia. Solution a) was adopted because this is how the previous dictionary had been edited.

As we can have a division of senses for lexical items in the dictionary, we can divide the senses of a proverb. The letters of the alphabet e.g. can be used to mark the subsenses. The following case shows what a complex situation is created by the partial overlapping of the semantical fields of the equivalent proverbs:

\section{Example 12:}

French proverbs Group A: with a positive connotation Hungarian proverbs Le tout, c'est de commencer [s'y mettre] ['the main thing is to begin'] Il n'y a si difficile que le commencement ['nothing is as difficult as the beginning'] Group B: with both connotations Il n'y a que le premier pas [acte] qui coûte ['only the first step [act] needs an effort'] Group $C$ : with a negative connotation

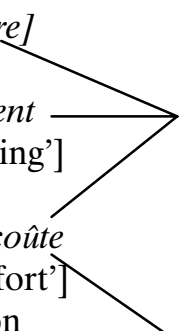

Minden kezdet nehéz

['every beginning is difficult']

$\uparrow$ equivalent for the 1 st sense equivalent for both senses: $\varnothing$ $\downarrow$ equivalent for the 2 nd sense

['there is no stopping on the slope'] 
The simplest way, as far as I know, is to say in the case of the French proverb of Group B, Il n'y a que le premier pas [acte] qui coûte, that there is a $1^{\text {st }}$ sense, with the Hungarian equivalent in Group $\mathrm{A}$, and a $2^{\text {nd }}$ sense, with the Hungarian equivalent in Group C. But it is unnecessary to make any comment in the Hungarian-French part of the dictionary about the different values of the French proverbs. From the point of view of the Hungarian proverb's equivalence with the French ones, it is irrelevant that the French proverb has another sense too.

\section{CONCLUSION}

To sum up: problems arise for two reasons. The first is that the lexemes and proverbs appear in the same material. This is due to objective reasons and it is unavoidable. The second one is that we are revising (and not compiling) a dictionary. And that is what needs to be changed. After having done the work, I realised the revision took me more time than the time I would have needed for compiling the material myself and that the result was not what I had expected.

Revising is working on paper, in other words the editor spends long-long hours with looking for the entry at which the editor of the previous edition liked to place a proverb, on deleting it there and placing it at some other entry and simultaneously, he revises the equivalences. The editor tries not to make too many changes, he tries to retain as much as possible, quantitatively and qualitatively, of the proverbs of the previous edition, and he leaves them where they are in the entries, scattered after each subsense of a lexeme, instead of listing all the proverbs of a lexeme together at the end of the entry. In cases where there is no one equivalent, as in example 12, the task of matching the proverbs and separating the senses is particularly difficult.

As the proverb says: It is easy to be wise after the event, so I can certainly recommend, in a similar case, not to revise the proverb lore of a general bilingual dictionary but to compile the material yourself. It will result in less work and - what is more important - it will lead to a much better result. You can work on a PC. First you select the material to be included and establish all the equivalences, and then you just have to underline the first significant word of the proverb to indicate to the publisher under which entry you want the proverb to be inserted. Whereas the revision of an old dictionary implies many constraints in the new dictionary. To use a Hungarian phraseological unit - it is as if the tail wagged the dog. 